\title{
Study of the Germination of Six Begonia Species as an Effort to Preserve Genetic Resources
}

\author{
Cokorda Istri Meyga Semarayani*, Ayyu Rahayu \\ Research Center for Plant Conservation and Botanic Gardens, Indonesian Institute of Sciences (LIPI), Indonesia \\ *Corresponding Author: meygacokorda@gmail.com
}

Submitted: 2021-05-18. Revised: 2021-06-13. Accepted: 2021-08-12

\begin{abstract}
Begonia is an ornamental plant that has a high level of morphological diversity. Begonia propagation is mostly done vegetatively and very rarely to propagate sexually. Therefore, this study was conducted to determine the ability of six types of Begonia seeds to germinate. Six types of Begonia, namely B. x albopicta W. Bull 'Coral Rubra', B. gambutensis Ardi \& D.C.Thomas, B. multistaminea Burt-Utley, B. nelumbifolia Schltdl. \& Cham., B. ulmifolia Wild. and B. varipeltata D.C.Thomas. were grown in a petri dish and placed in a growth chamber with a temperature of $23.6{ }^{\circ} \mathrm{C}$, humidity of $74.5 \%$, and a light intensity of 3,431 lux. The results showed that the different types of Begonia showed significant differences in all the parameters tested. B. nelumbifolia required $7.89 \pm 0.18$ days to germinate and is the fastest time than other types. The highest percentage of seed germination was also obtained by this species, amounting to $63.22 \%$. In addition, B. nelumbifolia showed the best response to the germination rate coefficient, germination rate index, and germination index. This study revealed complete information about the germination of six types of Begonia. The ability to produced many seeds and the ease of germination made this plant have the potential to be cultivated through seeds. Furthermore, the information can be used as a basis for seed storage as an $e x$-situ conservation method to maintain genetic diversity.
\end{abstract}

Key words: Begonia nelumbifolia; conservation; Eka Karya Bali Botanic Gardens; genetic diversity; seed

How to Cite: Semarayani, C. I. M., \& Rahayu, A. (2021). Study of the Germination of Six Begonia Species as an Effort to Preserve Genetic Resources. Biosaintifika: Journal of Biology \& Biology Education, 13(2), 222-229.

DOI: http://dx.doi.org/10.15294/biosaintifika.v13i2.30255

\section{INTRODUCTION}

Begonia (Begoniaceae) is one of the fifth or sixth largest taxa with more than 1,800 species. The morphological diversity of Begonia is high, and the actual number of these species in nature is estimated to be between 2,000 and 2,500 species (Haba, 2015; Tian et al., 2018). Begonia is one type that has been conserved by the Eka Karya Bali Botanic Gardens (BBG). The number of Begonia collections that have been conserved at BBG based on the Registration unit catalog as of February 2021 is 310 species.

Begonia is an ornamental plant that has a high level of morphological diversity (Haba, 2015). Most of the Begonia is a monoecious plant. That is, male and female flowers are in one plant. The female flowers can be recognized by the presence of an ovary in the form of a winged capsule. Pollinated flowers will form fruit and produce seeds. Begonia seeds are small and many. Efendi et al. (2019) stated that the seeds of several begonias were 252.42-451.25 $\mu \mathrm{m}$ long and 160.06-284.83 $\mu \mathrm{m}$ wide. Haba (2015) stated that Begonia schmidtiana fruit 'Chauncy' produces about 6,500 ovules per capsule. Not all of the ovules will become seeds, but this plant has the potential to produce many offspring in one flowering cycle. The problems are, male fertility is not necessarily linked to female fertility as different genes may underlie male and female meiosis, so it cannot produce seed easily (Dewitte et al., 2011).

Wahyuni and Siregar (2020) stated that the genus of Begoniaceae has been able to become one of the top priority taxonomic groups plant conservation in Indonesia because: (1) high endemicity; (2) can be reintroduced into nature; (3) potential to be conserved ex-situ; and (4) has an economic value as an ornamental plant because of its uniqueness and the beauty of the leaves. Begonia is generally included in plants that are easily propagated, both vegetatively and generatively. However, vegetative propagation of Begonia is more preferred than generative propagation. Shoot and leaf cuttings are the most common and easy propagation methods in Begonia. Information about the propagation of Begonia plants through seeds has not been done much. On the other hand, investigating seed storage behavior is needed for seed conservation strategies (Latifah et al., 2020). Efendi et al. 
(2019) stated that germplasm management through the seeds presents a challenge to ensure high-quality seeds are worth using and have a long saving power of life.

Based on this phenomenon, the study of Begonia propagation by seed is an interesting challenge to study. Measurement of germination can provide valuable information about initial, speed, uniformity, and final germination percentage (Soltani et al., 2015). Hay and Probert (2013) mentioned that research should be more focused on seed development and germination as a reference in implementing ex-situ conservation through seed banks. Therefore, this study aimed to examine the germination of the six types of Begonia seeds in BBG to be used as a basis for conservation purposes.

\section{METHODS}

This research was conducted from October to November 2020 at the Seed Bank Laboratory of the Eka Karya Bali Botanic Gardens - LIPI. The materials used were six types of Begonia from the BBG collection, namely B. $x$ albopicta W. Bull 'Coral Rubra', B. gambutensis Ardi \& D.C.Thomas, B. multistaminea Burt-Utley, $B$. nelumbifolia Schltdl. \& Cham., B. ulmifolia Wild. and $B$. varipeltata D.C.Thomas.

\section{Seed collection and preparation}

The six seeds were harvested from BBG's Begonia Garden in October 2020. The seeds were taken from ripe fruit that had been browned, and all parts of the fruit had dried on the tree, or the seeds were ripe for harvest. Furthermore, the seeds were separated from the fruit's skin and cleaned from other fruit parts manually. Cleaned seeds were weighted as much as 0.002 grams and counted for the number of seeds for each type (Table 1). The seed shape of each species was also observed with a binocular microscope Olympus CX-31.

Table 1. Number of seeds of six types of Begonia per 0.002 grams

\begin{tabular}{lc}
\hline Types of Begonia & Number of seeds \\
\hline B. x albopicta & 488 \\
B. gambutensis & 462 \\
B. multistaminea & 529 \\
B. nelumbifolia & 503 \\
B. ulmifolia & 532 \\
B. varipeltata & 472 \\
\hline
\end{tabular}

\section{Seed germination}

Each type of Begonia was germinated in a petri dish that had been laced with tissue paper moistened with water. Then the petri dishes were placed in the growth chamber with a temperature of $23.6^{\circ} \mathrm{C}$, the humidity of $74.5 \%$, and a light intensity of 3,431 lux. Watering was done using a micropipette twice a week or depending on needs. Observations were carried out every day for 30 days by taking the germinated seeds and observed under a Dino-Lite AM4515T5 digital portable microscope.

\section{Germination measurement}

The experimental parameters of germination in this study were based on $\mathrm{Al}$-ansari and Ksiksi (2016), namely:

a. Mean Germination Test (MGT)

MGT $=\sum$ seeds germinate $(\mathrm{G})$ on day $\mathrm{x} / \sum$ seeds germinate

b. Final Germination Percentage (FGP) $\mathrm{FGP}=$ (number of seeds germinated $/$ number of seeds sown) x $100 \%$

c. Coefficient Velocity of Germination (CVG) $\mathrm{CVG}=\mathrm{N} 1+\mathrm{N} 2+\ldots+\mathrm{Ni} / 100 \times \mathrm{N} 1 \mathrm{~T} 1+\ldots+\mathrm{NiTi}$ $\mathrm{N}=$ number of seeds germinated $\mathrm{T}=$ germinating day

d. Germination Rate Index (GRI) $\mathrm{GRI}=\mathrm{G} 1 / 1+\mathrm{G} 2 / 2+\ldots+\mathrm{Gi} / \mathrm{i}$ $\mathrm{G}=$ percentage of germination

e. Germination Index (GI)

$$
\mathrm{GI}=(20 \mathrm{x} \mathrm{G} 1)+(19 \mathrm{xG})+\ldots+(1 \mathrm{xG} 20)
$$

\section{Experimental design and statistical analysis}

The experiment was prepared with a onefactor, completely randomized design, namely the type of plant (six types of Begonia) repeated three times. The data obtained were analyzed using analysis of variance (ANOVA) using SPSS 16.0. If the variance results had a significant effect, then the data were proceed with the Least Significant Difference test (LSD) with significance level of $5 \%$.

\section{RESULTS AND DISCUSSION}

Begonia has specific characteristics, namely in the form of erect, shrub or creeping, with stems that watery, and asymmetrical leaf blade (begoniifolia), so easy to distinguish from other plants (Dewitte et al., 2011). Until 2020, the BBG has succeeded in collecting 310 Begonia consisting of native and exotic Begonia. Native Begonia was obtained from the exploration of plants in Indonesian forests like B. gambutensis, 
B. multistaminea, $B$. nelumbifolia and $B$. varipeltata. While the exotic Begonia were those had been widely cultivated by hobbyists and ornamental plant lovers like a B. $x$ albopicta. The plant used in this study is presented in Figure 1, and the microscopic appearance of seeds is shown in Figure 2.

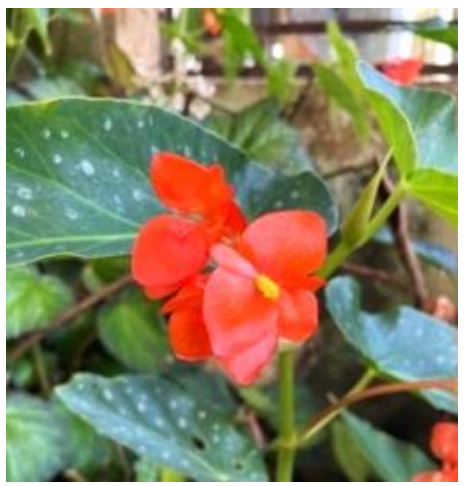

B. x albopicta

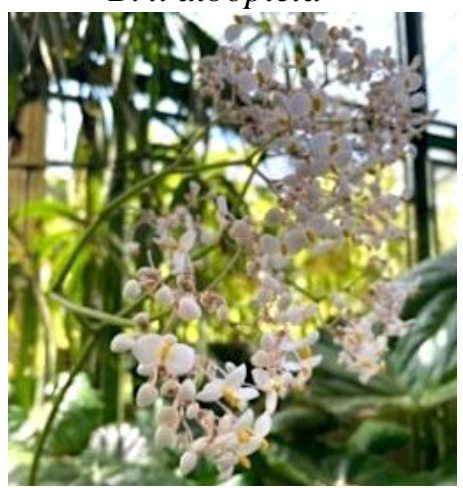

B. nelumbifolia

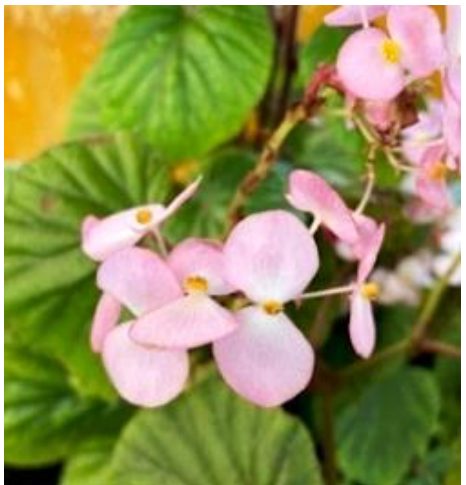

B. gambutensis

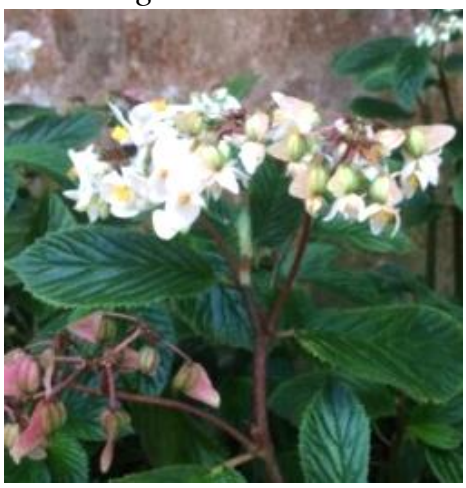

B. ulmifolia

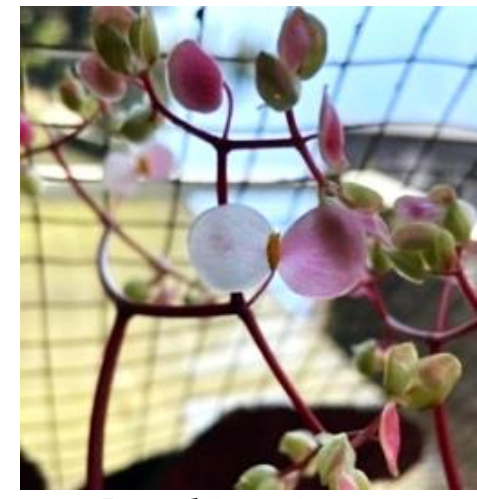

B. multistaminea

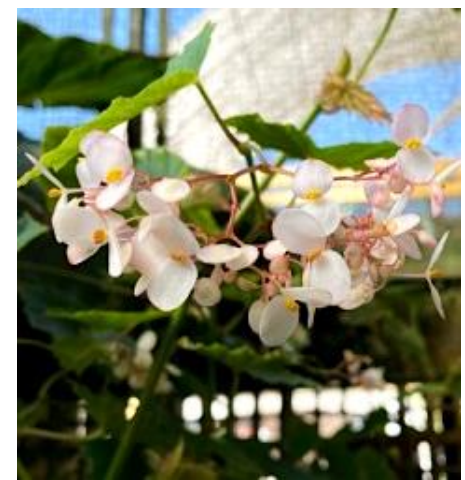

B. varipeltata

Figure 1. Six types of Begonia collection of Eka Karya Bali Botanic Gardens.

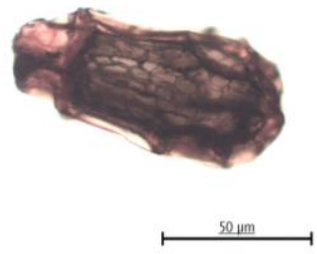

B. $x$ albopicta

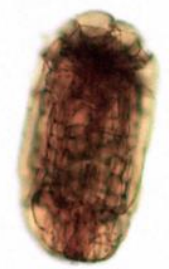

B. nelumbifolia
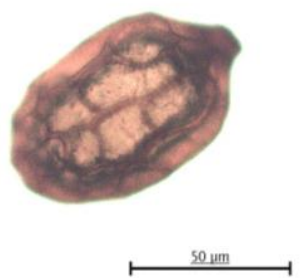

B. gambutensis

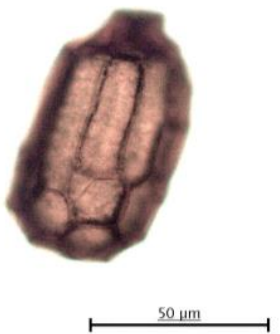

B. ulmifolia
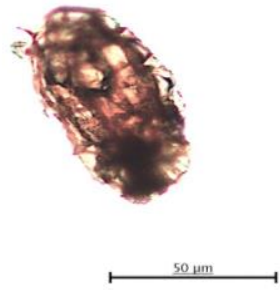

B. multistaminea

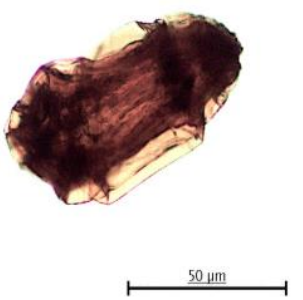

B. varipeltata

Figure 2. Microscopic appearance of six types of Begonia seeds. 
In general, the Begonia seed consists of four parts (Figure 3), including the hilum micropyle, which is the part that attaches to the fruit wall, operculum or seed cap, the collar cell of the seed that is split when germinating, which is a characteristic of Begonia seed, and the common part of the testa cell on the seed coat. Stages of germination start when imbibition seeds, and then the hypocotyl elongates and penetrates the operculum. Furthermore, the hypocotyl that penetrates the operculum develops into collets, which are structures that produce root hairs. At the bottom of the collet, the root meristem will appear. It occurs simultaneously with the development of the cotyledons on the other side of the hypocotyl (Haba, 2015). Based on the observation, all Begonia seeds show the same sprout growth. Likewise, $B$. fischeri, B. muricata and $B$. scottii had the same stages of germination (Haba, 2015; Efendi et al., 2019).

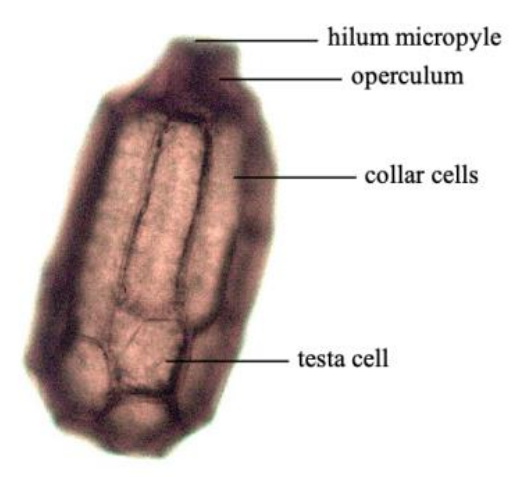

Figure 3. The parts of a Begonia seed

The different types of Begonia showed significant differences in all the parameters tested (Table 2). B. nelumbifolia seed has the best on average germination time, percentage of germination, germination rate coefficient, germination rate index, and germination index compared to the others. The average germination time is defined as the length of time it takes for one seed to germinate (Soltani et al., 2015; Alansari \& Ksiksi, 2016). The lower the average germination time value, the faster the seeds will germinate. The results of mean germination time are varied, from $7.89 \pm 0.18$ to $14.77 \pm 0.28$ days . The seed that germinates fastest was $B$. nelumbifolia and the one that takes the longest was B. gambutensis. These differences are not only caused by the species but also due to the maturity of the seeds. Zuhri (2017) mentioned the same results that seed maturity accelerates the germination process on Cestrum elegans.
The highest percentage of seed germination was B. nelumbifolia, which was $63.22 \%$ and followed by $B$. gambutensis was $52.6 \%$. Meanwhile, the others were below 50\%. Even $B$. $x$ albopicta germination was the lowest, which was $4.17 \%$. Germination of $B$. nelumbifolia began on the fifth day after the seeds were sown. Furthermore, most seeds germinate one day after the first seeds sprout and decreased with increasing observation time (Figure 4). This pattern is the same as that shown in $B$. multistaminea and $B$. ulmifolia. Meanwhile, different germination patterns are shown in $B . x$ albopicta, B. gambutensis and B. varipeltata. The initial period of germination is marked by a line parallel to the axis and then begins to rise and reach its peak on the second and third days after the first seeds germinate. The first and last days of germination showed significant differences between treatments. In this study, the highest germination index value achieved by $B$. nelumbifolia and the lowest was $B . x$ albopicta. This indicates that $B$. nelumbifolia undergoes faster initiation and end of germination than other types of Begonia.

The results showed that four types of Begonia had a germination percentage below $50 \%$, even B. $x$ albopicta was only $4.17 \pm 0.31 \%$. In general, it is caused by differences in genetic traits. Yamburov et al. (2020) reported different results, the percentage of $B$. ludwigii seeds that germinated was very high, namely $92.8 \%$, even though the sprouts started to appear in the second week. Saefudin and Wardiana (2013) stated that the varieties affect the speed of germination. The low germination rate may be caused by the seeds used have not reached the appropriate level of maturity. Seeds harvested from fruits that have not reached physiological maturity have embryos and other components that are not yet fully formed so that the seed vigor is low (Wulananggraeni et al., 2016). The level of fruit maturity also affected the dry weight of the seeds (Susanti et al., 2019). Darmawan et al., (2014) also mentioned that the dry seed weight affected the endosperm content of the seeds, thus causing differences in germination. Delaying harvest until the fruit is dry and ripe is recommended for $B$. areolata species. B. hooveriana, B. isoptera, B. kudoensis, B. Muricata, and B. sudjanae (Efendi et al., 2019).

Another factor thought to influence pollination is pollinators. Yamburov et al. (2020) stated that pollinating insects were one of the factors causing the low germination percentage 
of B. ludwigii grown in greenhouses. Without pollinating insects, plants can only pollinate geitonogamy, which means male flowers pollinate female flowers in the same inflorescence. If the male and female flowers do not emerge simultaneously, the seed productivity is low. Seed productivity can be increased by cross-pollination or xenogamy. Through this pollination, the seed productivity increased almost three times, up to $1587.8 \pm 75.8$ seeds per capsule (Yamburov et al., 2020).

Table 2. Value of germination parameters for six types of Begonia in Eka Karya Bali Botanic Gardens

\begin{tabular}{lccccc}
\hline \multirow{2}{*}{ Jenis begonia } & \multicolumn{5}{c}{ Parameter } \\
\cline { 2 - 6 } & MGT & FGP & CVG & GRI & GI \\
\hline B. x albopicta & $10.87 \pm 0.65 \mathrm{~b}$ & $4.17 \pm 0.31 \mathrm{a}$ & $9.22 \pm 0.57 \mathrm{~b}$ & $1.97 \pm 0.07 \mathrm{a}$ & $408.67 \pm 18.58 \mathrm{a}$ \\
B. gambutensis & $14.77 \pm 0.28 \mathrm{~d}$ & $52.67 \pm 3.92 \mathrm{~d}$ & $6.77 \pm 0.13 \mathrm{a}$ & $17.03 \pm 1.72 \mathrm{c}$ & $3951.67 \pm 362.15 \mathrm{c}$ \\
B. multistaminea & $10.95 \pm 0.82 \mathrm{~b}$ & $25.14 \pm 1.68 \mathrm{~b}$ & $9.17 \pm 0.71 \mathrm{~b}$ & $12.81 \pm 1.29 \mathrm{~b}$ & $2668.67 \pm 246.84 \mathrm{~b}$ \\
B. nelumbifolia & $7.89 \pm 0.18 \mathrm{a}$ & $63.22 \pm 2.76 \mathrm{e}$ & $12.68 \pm 0.30 \mathrm{c}$ & $41.26 \pm 0.72 \mathrm{~d}$ & $7347.00 \pm 264.76 \mathrm{~d}$ \\
B. ulmifolia & $10.74 \pm 0.10 \mathrm{~b}$ & $29.17 \pm 4.95 \mathrm{~b}$ & $9.31 \pm 0.09 \mathrm{~b}$ & $14.68 \pm 2.61 \mathrm{bc}$ & $3145.80 \pm 546.99 \mathrm{~b}$ \\
B. varipeltata & $13.88 \pm 0.37 \mathrm{c}$ & $38.63 \pm 7.10 \mathrm{c}$ & $7.21 \pm 0.19 \mathrm{a}$ & $13.61 \pm 2.55 \mathrm{~b}$ & $3122.67 \pm 585.19 \mathrm{~b}$ \\
\hline
\end{tabular}

Note: $\mathrm{MGT}=$ mean germination time; FGP $=$ final germination percentage; $\mathrm{CVG}=$ germination rate coefficient; GRI = germination rate index; GI = germination index; Numbers accompanied by the same letter in the same column do not show a significant difference based on the 5\% LSD test ( $\mathrm{p}=$ $0.05)$.

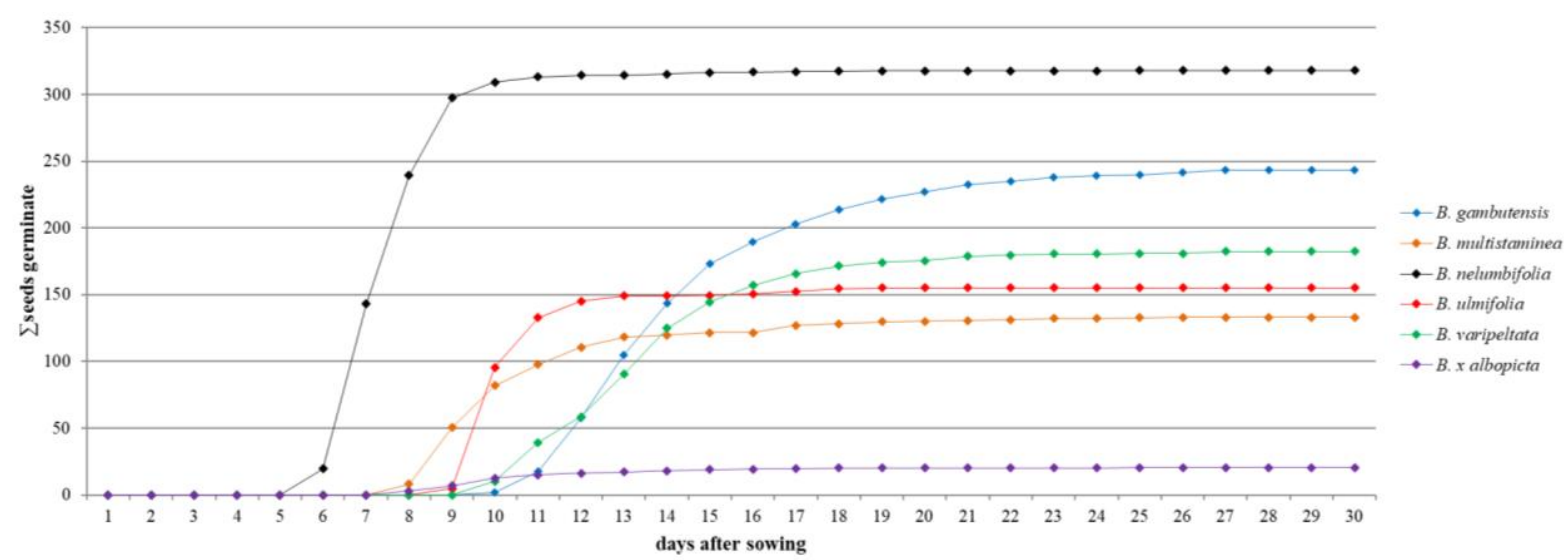

Figure 4. The number of seeds germinated in six types of Begonia in Eka Karya Bali Botanic Gardens

Begonia are found in varying habitats and altitudes, ranging from 19 to 2,300 masl (Ardi et al., 2014; Hughes \& Takeuchi, 2015; Hughes et al., 2015; Undaharta \& Ardi, 2016; Ardaka \& Ardi, 2019). Some species come from humid tropics and can only grow in environments with high humidity, while others prefer in dry conditions (Haba, 2015). In their natural habitat, the seeds of $B$. grandis subsp. evansiana may be dispersed at the end of the rainy season and will not germinate until after a dry winter (Haba, 2015). The seeds will experience dormancy during this time. Dormancy is a condition that causes seeds not to germinate even though they have been grown in optimal environmental conditions. A specific temperature is required for the seeds to germinate. Kumar et al. (2011) reported that the germination percentage of Andrographis paniculata Wall. ex Nees reached $95 \%$ when germinated at $25{ }^{\circ} \mathrm{C}$ and decreased at a temperature above or below. The seeds used in this study were collected from different habitats and conserved at BBG. B. $x$ albopicta, B. nelumbifolia and $B$. ulmifolia were from America, B. multistaminea was from Mexico and B. gambutensis and B. varipeltata were from Sulawesi and all were germinated at the same temperature of $23.6{ }^{\circ} \mathrm{C}$. This can lead to less than optimal seed germination. Haba (2015) stated that the germination of $B$. dregei reached its maximum at a temperature of lower than $12{ }^{\circ} \mathrm{C}$, reflecting the natural environment of the seeds in 
their natural habitat.

Several efforts can be made to increase seed germination, including soaking seeds in liquid smoke (Tang et al., 2020), immersion in GA3 (Herlina \& Aziz, 2016), giving Plant Growth Promoting Rhizobacteria (PGPR) (Wahdah et al., 2018), and hydropriming (Herlina \& Aziz, 2016). Tang et al. (2020) stated that peanut seeds soaked with liquid smoke had more lateral roots. Furthermore, the provision of GA3 had a significant effect on the length of the radicle of black cumin seeds grown in a germinator at a temperature of $25 \pm 1{ }^{\circ} \mathrm{C}$ (Herlina \& Aziz, 2016). Normal root growth will maximize nutrient absorption so that it can accelerate the formation of normal sprouts. Germination can also be stimulated by the biostimulants contained in PGPR. Wahdah et al. (2018) reported that the single PGPR application and the interaction with the variety and duration of seed storage significantly affected the increase in germination, synchronous seed growth, and rice speed seeds after three months of storage. In addition, seed viability can be increased by hydropriming treatment. Herlina and Aziz (2016) stated that hydropriming affected the germination and vigor of black cumin seeds. Hydropriming is a hydration-dehydration process by immersing seeds in water as an effort to increase seed viability. During the priming process, the need for water in the seeds is sufficient to produce radicles, prepare for the metabolic process, and then starting the germination process (Herlina \& Aziz, 2016).

The seed is part of a plant that stores high genetic diversity because it combines two genetic information through crossing or mating. To prevent future loss of genetic resources of various species, seed storage for ex-situ conservation is recommended. Hay and Probert (2013) stated that seed development studies are needed, for example, to identify germination of species, to predict how to conserve and how seeds develop because each species has specific traits. The data obtained, such as average germination time, percentage of germination, germination rate coefficient, germination rate index, and germination index that indicated the germination pattern of Begonia affected by the species. This complete information about the germination of six types of Begonia were new data that had not been presented in previous Begonia studies, which revealed more about new species and their morphological variations. In addition, Begonia could produce many seeds and had the ease of germination made this plant potential to be cultivated through seeds. Therefore, these results provided an alternative way to propagate this plant other than vegetatively. Further studies on storage time and possible seed deterioration are needed as an effort to conserve Begonia seeds ex-situ, and the results will be beneficial for BBG staff, as well as for Begonia breeders and collectors.

\section{CONCLUSION}

The six types of Begonia seeds can germinate based on germination time, percentage of germination, germination rate coefficient, germination rate index and germination index. Among all, B. nelumbifolia was the highest for all the parameters. Subsequently, information about the germination of six types of Begonia can be used as a basis for seed storage as an exsitu conservation method to maintain genetic diversity.

\section{ACKNOWLEDGMENT}

The author would like to thank Ketut Sumertana at Begonia Park and Gusti Ayu Made Candiwati at the Seed Bank Laboratory for contributing to this research.

\section{REFERENCES}

Al-ansari, F., \& Ksiksi, T. (2016). A quantitative assessment of germination parameters: the case of Crotalaria persica and Tephrosia apollinea. The Open Ecology Journal, 9, 1321.

Ardaka, I. M., \& Ardi, W. H. (2019). A new species of Begonia (Begoniaceae) from the Moluccas, Indonesia. Gardens' Bulletin Singapore, 71(2), 415-419.

Ardi, W. H., Ardaka, I. M., Hartutiningsih-M, S., Lugrayasa, I. N., \& Thomas, D.C. (2014). Two new species of Begonia (Begoniaceae) from Sulawesi, Indonesia. Edinburgh Journal of Botany, 71(2), 259-268.

Darmawan, A. C., Respatijarti, \& Soetopo, L. (2014). Pengaruh tingkat kemasakan benih terhadap pertumbuhan dan produksi cabai rawit (Capsicum frutescent L.) varietas comexio. Jurnal Produksi Tanaman, 2(4), 339-346.

DeWitte, A., Twyford, A., Thomas, D., Kidner, C., \& Van Huylenbroeck, J. (2011). The origin of diversity in Begonia: genome 
dynamism, population processes and phylogenetic patterns. The Dynamical Processes of Biodiversity - Case Studies of Evolution and Spatial Distribution, InTech, 27-52.

Efendi, M., Handayani, A., \& Lailaty, I. Q. (2019). Short communication: seed germination of twelve Indonesian begonias for conservation. Biodiversitas, 20(4), 11921197.

Farooq, M., Basra, S. M. A., \& Hussain, M. (2007). Incorporation of polyamines in the priming media enhances the germination and early seedling growth in hybrid sunflower (Helianthus annuus L.). International Journal of Agriculture and Biology. 9(6), 868-872.

Haba, S. R. (2015). Conservation of begonia germplasm through seeds: characterization of germination and vigor in different species. Thesis. Columbus: Horticulture and Crop Science Program, The Ohio State University.

Hay, F. R., \& Probert, R. J. (2013). Advances in seed conservation of wild plant species: A review of recent research. Conservation Physiology, 1(1), 1-11.

Herlina, N., \& Aziz, S. A. (2016). Peningkatan viabilitas benih jintan hitam (Nigella sativa) dengan hidropriming dan pemberian asam giberelat. Buletin Penelitian Tanaman Rempah dan Obat, 27(2), 129-136.

Hughes, M., Girmansyah, D., \& Ardi, W.H. (2015). Further discoveries in the everexpanding genus Begonia (Begoniaceae): Fifteen new species from Sumatera. European Journal of Taxonomy, 167: 1-40.

Hughes, M., \& Takeuchi, W. (2015). A new section (Begonia sect. Oligandrae sect. nov.) and a new species (Begonia pentandra sp. nov.) in Begoniaceae from New Guinea. Phytotaxa, 197(1), 37-44.

Kumar, B., Verma, S.K., \& Singh, H.P. (2011). Effect of temperature on seed germination parameters in Kalmegh (Andrographis paniculata Wall. ex Nees.). Industrial Crops and Products, 34(1), 1241-1244.

Latifah, D., Wardani, F. F., \& Zulkarnaen, R. N. (2020). Short Communication: Seed germination, seedling survival and storage behavior of Koompassia excelsa (Leguminosae). Nusantara Bioscience, 12(1), 46-49.

Saefudin \& Wardiana, E. (2013). Effect of Varieties and Fruit Maturation Stages on Germinations and Physical of Arabica Coffee Seeds. Journal of Industrial and Beverage
Crops, 4(3), 245-256.

Soltani, E., Ghaderi-Far, F., Baskin, C. C. \& Baskin, J. M. (2015). Problems with using mean germination time to calculate rate of seed germination. Australian Journal of Botany, 63(8), 631-635.

Susanti, N. D., Widajanti, E., \& Guntoro, D. (2019).

Studi perkecambahan benih ciplukan (Physalis peruviana L.) pada beberapa tingkat masak buah. Buletin Agrohorti, 7(3), 263-269.

Tang, B. Y., Vertygo, S., Lema, A. T., \& Swari, W.D. (2020). Analisis laju perkecambahan kacang tanah (Arachis hypogaea (L.) Merr.) yang diberikan kombinasi perlakuan suhu dan lama perendaman asap cair (liquid smoke). Jurnal Penelitian Pertanian Terapan, 20(1), 65-73.

Tian, D., Xiao, Y., Tong, Y., Fu, N., Liu, Q., \& Li, C. (2018). Diversity and conservation of chinese wild begonias. Plant Diversity, 40(3), 75-90.

Undaharta, N.K.E., \& Ardi, W.H. (2016). Studies on Begonia (Begoniaceae) of the Moluccas III: A new Begonia from Seram, Indonesia. Gardens' Bulletin Singapore, 68(02), 279-285.

Wahdah, R., Aidawati, N., \& Arisandi, N. (2018). Penggunaan Plant Growth Promoting Rhizobacteria (PGPR) untuk perbaikan performa viabilitas benih beberapa varietas padi (Oryza sativa L.) setelah penyimpanan selama tiga bulan. in Prosiding Seminar Nasional Lingkungan Lahan Basah, 3(1), 8695.

Wahyuni, S., \& Hartutiningsih-M, S. (2020). Keragaman dan analisis kekerabatan 30 jenis Begonia berdasarkan karakter morfologi. Buletin Kebun Raya, 23(2), 91-103.

Wiriadinata, H., \& Girmansyah, D. (2001). Potensi begonia liar sebagai tanaman hias. in Prosiding Seminar Sehari Menggali Potensi dan Meningkatkan Prospek Tanaman Hortikultura Menuju Ketahanan Pangan, 208-2013.

Wulananggraeni, R., Damanhuri \& Purnamaningsih, S. L. (2016). Pengaruh perbedaan tingkat kemasakan buah pada 3 genotip mentimun (Cucumis sativus L.) terhadap kualitas benih. Jurnal Produksi Tanaman, 4(5), 332-341.

Yamburov, M. S., Lykhina, A. I., Romanova, S. B., Smolina, V. M., \& Zharnakova, E. Y. (2020). Reproductive biology of a rare 
Cokorda Istri Meyga Semarayani et al. / Biosaintifika 13 (2) (2021): 222-229

species Begonia ludwigii in greenhouse conditions of the Siberian Botanical Garden of Tomsk State University'. in IOP Conference Series: Earth and Environmental Science, 421(5), 1-6.
Zuhri, M. (2017). Pola perkecambahan biji tanam-an berpotensi hias dan invasif Cestrum elegans (Brongn. ex Neumann) Schltdl. in Seminar Nasional Biologi 2 (SEMABIO) 2017 Pemanfaatan Biodiversitas Berbasis Kearifan Lokal, 113-122. 